\title{
The relevance of Marx to contemporary perspectives on Utterance Meaning in Context: a re-examination of Voloshinov's Philosophy of Language
}

\begin{abstract}
Philosophers on all sides of the contemporary Contextualism debates have given primacy to the role context plays in utterance comprehension. They view language as a socio-cultural practice; their theoretical perspectives are largely focused on speaker's intentions and contextually modified senses of language elements appropriate to the situation at hand. Following Marx and Engels' (1845) philosophical contributions on language, Voloshinov (1929: 9-24, 83-98) argues that language can only exist if socially organised individuals engage and communicate through the use of 'signs'. The object of study should be the language of 'actual life', in other words utterances that carry meaning in existent social contexts, as well as interactions between interlocutors which alter and shift in real socio-historical conditions. The central tenet of this paper is to examine and advocate the use-value of language key to both contemporary philosophical thought on language and that of Marx. The latter however has had little or no impact on the former. Using Voloshinov's (1929) framework, which gives primacy to the historical and social character of language, we argue for a (re)introduction of a Marxist Philosophy of Language into current philosophical debates as its contribution is essential in assessing the impact of language use on social consciousness.
\end{abstract}

\subsection{Introduction}

Contemporary philosophical debates on sentence meaning/speaker meaning, and the role of context in utterance comprehension, have moved on from the very early antagonisms associated with 'ideal language philosophy' and the camp of the socalled 'ordinary language philosophers'. The former gave rise to contemporary 'formal semantics' and the latter contributed to the view currently known as 'Contextualism' (for detail on both currents, see for example Bach 1999, Carston 2007, Recanati 2002a and 2002b; Stainton 2010). Those early disagreements appear to have been settled on two accounts: semanticists have conceded that contextsensitivity in natural language cannot be ignored; those working in pragmatics (Contextualists) appear no longer to hold that 'meaning is use', having been led by Grice to draw a distinction between what an expression means and what its use conveys in a particular context. Recently however there have been some attempts by 'Radical Contextualists' to revisit the question of whether linguistic meanings necessarily serve as 'input' to the contextual construction process. This sceptical view is representative of Austin and Wittgenstein according to which "truth-conditional content is... unstable and context-dependent" (Recanati 2004: 141) ${ }^{1}$. The 'construction' process can thus proceed without the help of conventional word meanings. This development is important and I will address it in more detail later on.

\footnotetext{
1 Austin and Wittgenstein are the most frequently recognised predecessors of contemporary Radical Contextualism. Their ideas can be recognised in the more contemporary works of Radical Contextualists, such as Predelli (cf. 2005), Recanati (cf. 2000, 2004, 2007a, 2007b), Travis (cf. 1997, 2008).
} 
However, those philosophers of language who have abandoned Wittgenstein's thinking and have firmly stuck with Grice (most of them), have since the mid 1970s/early 1980s undergone sustained critical scrutiny by 'Integrational linguists' who claim that "a theory of language must be developed within a theory of communication" (Hutton 2011: 475). The integrationist position was pioneered by Harris (1981, 1996, 1998) who did not accept the Gricean distinction between 'natural' and 'non-natural' meaning, emphasising the need for a broader conception of use that better captures the necessary links between verbal and non-verbal communication during participants' exchanges. For Harris, identifying types of meaning independently of context is a non-starter: signs are always made by the participants and sign-making is reflective of individuals" "communicational proficiency" (Harris 1998: 44). Thus 'mind reading' (commonly presupposed in contemporary philosophy of language, in particular perhaps in Relevance Theoretic accounts of utterance meaning in context), is heavily criticised as it rests on the assumption that thoughts, ideas, meanings are somehow transmitted between different minds, a process Harris $(1981,1996)$ calls 'telementation'. This telementational position is consequent upon the premise that meanings are semantically preestablished (to a point) but that their more specific 'values' arise as a result of a particular communicative situation. Both of these claims are rejected by Integrationists outright: 'values', they claim, are assigned as part of the integration of activities involved since communication is the basis upon which continuous making and re-making of meanings takes place. 'Segregationists', as Harris calls them, appear to be charged with the following: (a) their distinction between 'what is said' and 'what is meant' (as in all Gricean-type accounts) leads back to 'mindreading'/'telementation' which necessarily assumes some level of conventional word meaning; and (b) the distinction in (a) is reflective of 'intention' based models of communication which assume that participants can somehow predict communicational processes that are to happen. Harris and others claim that in 'normal' communicative settings quite the opposite is the case; it is the communication amongst participants that creates contexts - these are unique and develop all the time as communication itself develops. Participants therefore do not share "conceptual or perceptual content" (Jones 2016: 36).

For Marxists interested in critical language research and communication, such divergences between approaches to language create space for reviving important debates on the use-value of language and therefore 'the social' element in language theory. This is because such approaches, in different ways, attempt to understand and examine progressive transformations of social life, and by so doing place language in a central position in relation to social change. Philosophically, as already illustrated, this is mainly achieved by exploring the role of utterances in communicative settings and examining communication at key moments in the process of social change where the object of study should be real life language use. These social, and historical, dimensions of language (largely labelled 'context', often 'narrow' and 'wide' context in contemporary philosophy of language) can be clearly detected in Voloshinov's Marxism and the Philosophy of Language. Here, language is not an abstract system; its use in concrete social contexts, and thus utterances used in concrete situations, should be the object of our study. 
With this prelude in mind, the key aim of this paper is to contribute to the current debates in philosophy of language by arguing that Voloshinov's position on meaning and use in language continues to have currency and deserves a more prominent place on the contemporary philosophical scene. This is both to critically (re)engage with Marx and contribute further to our understanding of the role of context in language use. In doing so, perhaps two other aims might be considered: i) showing that perhaps Integrational Linguistics and (Radical) Contextualism have something in common that is also shared with Voloshinov's framework; and ii) using real language examples to illustrate how those moments of actual social change are registered in 'the word' (following Voloshinov). With the second point I aim to show how redefined meanings are ever present in a society marked by inequalities, and how those meanings in frequently changing contexts impact on our social consciousness in moments of struggle. I will illustrate this shift by drawing on the 2010 student protests in the UK.

\section{0 'The social' in language theories}

I begin by giving a brief account of an example I wish to use throughout to illustrate real life language use and the significance of socio-political and historical contexts. The example comes from the work of a grassroots campaign set up in 2010/11 as a consequence of mass student protests in the UK. Students took to the streets to protest against tripling of tuition fees and abolition of the Education Maintenance Allowance ${ }^{2}$ by the then Coalition government (Conservatives and Liberal Democrats). The campaign's main focus ${ }^{3}$ was to challenge unlawful policing, and provide support and advice for student protesters who found themselves at the mercy of brutal policing tactics which left many severely injured. The campaign also focused on exposing a persistent campaign of intimidation by, disproportionate charges brought against students by the Crown Prosecution Service and a long smear campaign in the media ${ }^{4}$. Following Voloshinov's theoretical framework and drawing on Collins's (1996, 1999) analysis of the link between language and its socio-political and historical contexts, language extracts will show the development and shifting of the narrative of 'violence'. The data will assist in registering a redefinition of meaning at the moment of a particular struggle and in exposing the ways in which language is deployed by powerful minorities with the intention of marginalising the majority. More specifically, the language examples will show an initial portrayal of protesters as a 'violent mob' (via a media smearing campaign) and then a shift in that narrative, largely achieved through tireless campaigning and exposure of evidence in court which resulted in acquittals of the majority of students. The shift in narrative, and the discourse around an interpretation of visual evidence during court hearings, eventually exposed the deployment of violent tactics by the police.

\footnotetext{
2 Education Maintenance Allowance is a financial scheme applicable to students and those undertaking unpaid work-based learning between the ages of 16 and 19 whose parents had a certain level of taxable income. It was abolished in England in 2010; it is still available in Wales, Scotland and Northern Ireland.

3 Details of the 'Defend the Right to Protest (DtRtP)' Campaign's work and activities can be found here: www.defendtherighttoprotest.org

${ }^{4}$ All information and materials used in this paper are publicly available via websites, other publications and public reports.
} 


\subsection{Role of utterances}

In the 1929 Russian publication of Marxism and the Philosophy of Language, Voloshinov sets out a Marxist account of language, firmly rooted in the historical materialist method of analysis. In particular, Voloshinov began from the philosophical position advanced by Marx and Engels (1845: 51) two centuries earlier according to which language is humans' concrete, "practical consciousness" and which, Voloshinov argues (1929), can only exist if socially organised individuals engage and communicate through the use of 'signs'. From this perspective, language use is inherently social and historical in nature. Language itself, therefore, is not to be understood as an abstract entity (more indicative of the position of 'ideal language philosophy'); rather, our concern should be with the actual use of language in concrete situations and social contexts. This position has a number of distinctive and significant consequences for how we might understand the production of linguistic meaning.

Firstly, the object of study for Voloshinov is an 'utterance'; utterances are concrete manifestations of language use. They are spoken by living subjects, located within a specific social and historical perspective, and, importantly, are addressed to others as responses to their utterances. The focus on utterances thus reveals the various processes of change, shifts and developments "without which language would have no history to speak of" (Collins 2000: 44). Relatedly, meaning, as embodied in word, is therefore a product of the reciprocal relationship between speaker and listener, addresser and addressee (Voloshinov 1986: 99-106). This reciprocity entails a dialogicality of the utterance on two levels: utterances are spoken by "living subjects" in concrete social contexts (Collins 1996: 74), and at the same time represent verbal interaction between interlocutors in continually shifting real socio-historical conditions. Thus, "verbal interaction is the basic reality of language" (Voloshinov 1986: 94).

There are important similarities between this aspect of Voloshinov's work and contemporary Contextualist positions on utterance meaning. The key similarity rests on the role utterances play in communication, and more specifically in that their interpretation is taken to be context-dependent. Thus context (real, concrete situations) plays a vital part in the working out of a reciprocal relationship between a speaker and a hearer, including the working out by each participant of the meaning of the other's utterances. The circumstances under which utterances are produced necessarily form an essential element in utterance comprehension. These circumstances are also central for the assignment of truth conditional content of utterances, an essential formal element of (Radical) Contextualist frameworks. Importantly, the Radical Contextualist position considers truth-conditional content unstable, in other words entirely context/situation/discourse-dependent (Recanati 2004: 146-151). Its instability is therefore entirely down to transitions and shifts of circumstances. Radical Contextualist frameworks on language and communication (cf. Recanati 2004, 2007a) suggest, arguably in the spirit of Voloshinov, that word meanings are susceptible to variation, pretty much indefinitely. Words are associated 
with situations of use, nothing else. Thus to define the meaning of a word is to describe the type of situation in question. Recanati's (2004) radical philosophy of language recognises therefore the importance of communicative devices in shaping particular contexts.

Arguably, in this respect Voloshinov's position might be closer to the Integrationist point of view on utterance meaning in context (e.g. Harris 1996; 1998). On such a reading, context should not be conceived of in terms of a previously construed setting; rather, it is the participants themselves who are part of the context and who make it what it is by their engagement through various activities. Context is not given but constructed by the participants engaged in the communication process itself: "communication creates contexts" (Harris 1996: 163).

Nonetheless, what is missing from both Radical Contextualism and Integrationism is, first, an explicit recognition and, second, an analysis of the social and historical nature of language use which would help expose the traces of power and domination in language and the conflicts associated with them. Whilst the dialogical character of language in Voloshinov's sense is generally assumed in both endeavours, what is clearly only present in Voloshinov's framework is his dialectical conception of language through which he emphasises the inherently social and historical character of language.

To illustrate the theoretical issues at stake in the construction of context by participants let us turn to the case study example. The criminalisation of student protesters that took place after the 2010 protests was based on a reconstruction of the political narrative of the protest, a reconstruction which, for a significant period of time, masked how police violence contributed to shaping that narrative. The use of the Public Order Act 1986 against protesters had significant political implications because it diverted public attention away from the political message of the protesters. Instead, they were presented as having engaged in disorderly and criminal behaviour. This construal of context prevailed in the media reporting, both in right-wing and more liberal newspapers. Below are extracts which highlight a particular choice of vocabulary used in media reporting at the time to channel the narrative away from the reasons why protesters took to the streets and towards discourses which any 'morally responsible agents' would condemn. In particular, we see the use of metaphorical expressions "the siege" (of Millbank) and protesters "forcing" their way inside, commonly present in 'war' metaphors. This illustrates the narrative of violence and aggression used by the media to divert attention from the issues facing the education system at the time. Similarly, an adjectivally modified phrase "violent break-away" and adjectives "masked and hooded" help focus the reader on the disorderly and criminal behaviour of protesters. The reporting of "missiles raining down" and police being "outnumbered and overwhelmed" resembles a kind of reporting typical of war situations where one side are the losers and the other are winners. Continuing with the 'battle' theme, we note a description of the police being "relentlessly hemmed against the front of the building", indicating an intentional construction of a context involving violent, unruly and dangerous protesters. Here are the extracts: 
The siege of the Millbank office complex, ending with the smashing of the windows and the occupation of the building, was a violent break-away from what had until then been a noisy but good-natured march against raising tuition fees.

\section{Missiles thrown}

As more people crowded around the building, including some masked and hooded demonstrators, the mood changed. It became clear that there was going to be an attempt by some demonstrators to force their way inside. Missiles began to fly towards the large plate glass windows across the front of the building...

Outnumbered and overwhelmed, this line of policemen was slowly but relentlessly hemmed against the front of the building, missiles raining down on them.

\section{BBC, 11 Nov 2010}

Underlined elements above illustrate Voloshinov's view of the role of the word as "the most sensitive index of social change" (Voloshinov 1986: 19). In its process of growth, without a pre-determined shape, the word has "the capacity to register all the transitional elements and momentary phases of social change" (Voloshinov 1986: 19). Countless past examples of social conflict, in addition to the above, have shown that protest is embarrassing for any government. It is a loud, visible manifestation of dissent and discontent. Thus, the extracts above, and those further on, direct the reading public (conceivably shaping their views as a consequence) towards a representation of demonstrators who throw 'missiles', 'force' entrance, invoking a stereotype of those who 'mask up' or wear 'hooded' clothing and whose messages cannot be considered legitimate or serious, thereby diverting the public's attention away from the issues at hand.

The media reports below are also constructed narratives since these continue in the spirit of the representation of protesters illustrated in the above examples; only this time these representations appear to be further legitimised since they come from elected Members of Parliament, from ostensibly incontestable CCTV footage, and from eye witnesses. Underlined elements in the texts demonstrate that the focus on the criminality aspect of protesters' behaviour is particularly prominent with such adjectivally modified phrases "violent faction", "criminal acts"; and noun phrases "the criminals" and "this violence". The second extract from the Telegraph is perhaps even more interesting since it appears to adopt an informal style of reporting akin to the British tabloid press, reporting a judgement without trial of "the culprits". The readership is directed towards a perception that the "criminal acts" were pre-planned: the noun phrase "snarling faces" certainly hints at a pre-meditated action on the part of "the hooligans". The political narrative we spoke of above around the 2010 student protest can also be detected in the reference to "anarchist slogans" in the extract. The newspaper does not specify or clarify the nature of the slogans, or how one would go about identifying what these might be. However in historical terms, anarchism is 
primarily associated with absolute disregard for the rule of law, thus solidifying further the now familiar descriptions of the protesters and ignoring the politics of the educational agenda of the Coalition Government at the time.

David Cameron has called for the "full force of the law" to be used against people who assaulted police or damaged property during protests about student tuition fees.

Outlining yesterday's events to MPs, Mr Herbert said a "violent faction" had "directed a series of criminal acts" against the office complex on Millbank following the demonstration.

'The police are committed to bringing the criminals who carried out this violence in front of a court," Mr Herbert said.

\section{The Telegraph 11 Nov 2010}

Hundreds of hours of CCTV and television news footage will be studied, together with thousands of photographs, by officers trying to put names to the snarling faces of the culprits.

Witnesses said many of the hooligans who destroyed the ground floor of the building and sprayed anarchist slogans on the walls had left by the time police gained control of the situation and made arrests.

\section{The Telegraph 12 Nov 2010}

The Telegraph's reporting of 'hooligan'-style, 'violent' behaviour by 'criminals' who must be brought in front of a court may have contributed to the launching of criminal prosecutions under the Public Order Act 1986, in particular through the charge of Violent Disorder which carries a maximum term of five years' imprisonment. Its use represents a practice of 'over-charging' by the police and the Crown Prosecution Service (CPS). ${ }^{5}$ At the time, pressure was placed on individuals to plead guilty, leading to students receiving unjustified or disproportionate sentences as part of a wider programme of deterrence and intimidation. Alongside the narrative exemplified above, in which the language of the minority elite is deployed to marginalise and subordinate the majorities in their attempts to influence social change, was the practice of heavy-handed, often violent policing which took place during those events. ${ }^{6}$

However, despite many attempts by the media (and the UK Government via the media) to present the narrative we have analysed, an alternative perception of the

\footnotetext{
5 Details of research and case studies undertaken to show this trend, can be found on the following websites:

https://greenandblackcross.org/ (Green and Black Cross)

http://ldmg.org.uk/ (Legal Defence and Monitoring Group)

${ }^{6}$ Further information can be found here:

https://static1.squarespace.com/static/562e7d33e4b0da14ad6d202f/t/566f1b065a5668815911b14d/14 50121990831/SocialistLawyer58.pdf (pages 12-17)
} 
2010 student protest was being shaped by the events that surrounded a protester who underwent life-saving emergency brain surgery after being hit on the head by a police baton; he was at the same time charged (later acquitted) with violent disorder. The now iconic images of the student's injuries and postoperative trauma that flooded social media, and eventually saturated the more traditional news channels, continue to signify the face of brutal and unlawful policing. ${ }^{7}$ A similar media narrative was constructed around another student. Once again, the discourse was shaped using the familiar theme of violent and hooligan-style behaviour. In the media reporting of this case (a continuation of the extract above), the Prime Minister at the time, David Cameron, claimed that the police were "dragged off horses and beaten". ${ }^{8}$ In section 2.3 I will discuss the outcome of this particular case as part of the discussion of the contestable nature of language in practice.

\section{2 'We all speak the same language'}

Voloshinov argues that in any society groups with profoundly different viewpoints share a single language. When they speak, different meanings are produced by the use of the same words. The word therefore "sensitively reflects the slightest variation in social existence" (1986: 23). Competing meanings within a sign community are differentiated by differently oriented social interests, in other words "by the class struggle" (1986: 23). His comment in full:

Class does not coincide with the sign community, i.e. with the community which is the totality of users of the same set of signs for ideological communication. Thus various different classes will use one and the same language. As a result, differently oriented accents intersect in every ideological sign...The ruling class strives to impart a supraclass, eternal character to the ideological sign, to extinguish or drive inward the struggle between social value judgments which occurs in it, to make the sign uniaccentual...In actual fact, each living ideological sign has two faces, like Janus. Any current curse word can become a word of praise, any current truth must inevitably sound to many people as the greatest lie.

(Voloshinov 1986: 23)

The 'coincidence' of social class and language use is thus most clear in periods of social crisis when it truly becomes an "arena of class struggle" and helps expose the

\footnotetext{
7 Detailed information of Alfie Meadows case and iconic images of his injures can be found here: https://www.telegraph.co.uk/news/politics/8201657/Theresa-May-faces-questions-over-injured-AlfieMeadows.html

https://www.theguardian.com/education/2013/mar/08/student-tuition-fees-cleared-disorder https://www.independent.co.uk/news/uk/home-news/alfie-meadows-calls-on-ipcc-to-re-openinvestigation-into-student-protest-8529544.html https://www.theguardian.com/world/2010/dec/10/student-operation-tuition-feesprotest?INTCMP=SRCH

https://www.theguardian.com/uk/2010/dec/12/police-injured-protester-hospital?INTCMP=SRCH

http://defendtherighttoprotest.org/files/images/dtrtp_justice_for_alfie_meadows_highres.jpg

https://www.youtube.com/watch?v=tSfdHvT0fZY

8 Information about the case can be found here:

https://www.channel4.com/news/met-police-compensates-brothers-caught-up-in-protests https://www.theguardian.com/politics/2015/sep/23/cameron-urged-apologise-student-tuition-feesprotesters-compensation-hilliard
} 
conflict between the oppressed and those in a position of power who "seek to prevent and inhibit the development and dissemination of forms of speaking which might penetrate their claims to legitimacy" (Collins 2000: 44). Voloshinov's arguments play out in the example of the 2010 education demonstrations and their aftermath. Particular connotations attached to the vocabulary of violence - the 'unruly', 'immoral' behaviour of 'hooded', 'anarchist' 'hooligans' with 'snarling faces' - serve to mask the competing meanings of the communicative and other actions of students' and lecturers' groups. Moreover, those 'singular' meanings, constructed within a particular narrative that inhibits diversity of opinion, serve to reinforce the political agenda of the powerful groups, in this case the police working together with the state, both to create a biased narrative where the police are the victims and the protesters are the perpetrators, and to use such a narrative to justify the implementation of policing strategies on the ground that undermined the demonstrators' basic democratic rights to express dissent through protesting.

Many authors who have examined Voloshinov's work commonly point to his rejection of 'abstract objectivism' and of the existence of linguistic form as an abstract entity capable of surviving as a historically and socially isolated entity. Linguistic form, he argues, is only possible in the context of specific utterances, which in turn only exist in a specific ideological context. "Words", he says, "are always filled with content and meaning drawn from behaviour or ideology"; we never say or hear 'words' - "we say and hear what is true or false, good or bad, important or unimportant, pleasant or unpleasant, and so on" (1986: 70). In this respect too there is no doubt that he is arguing for the inherently social nature of language: the context sensitivity of utterances is reflected in the "contestable" nature of language (Collins 1996: 75), in other words issues pertinent to a particular social group unsurprisingly reflect their own social position and perspective. Utterances therefore carry distinctive "evaluative accents": a change in meaning is always a re-valuation.

Similarities between Voloshinov's position and both Radical Contextualist and Integrationist positions are in my view visible. Within the realm of 'Situation Theory', for example, a Radical Contextualist would argue that the truth-conditional content of any utterance is unstable and context-dependent (Recanati 2004).

Moreover, we should look for context-dependence in the circumstances of utterance and it is this that has a bearing on the context-dependence of utterance content - a 'top down' picture that evidently gives primacy to context over content, much like the Integrationist approach in some respects. In order to perform any semantic evaluation, we necessarily need to evaluate and re-evaluate the circumstances in which utterances are used rather than a putative semantic meaning of words or utterance (Recanati 2000). This theoretical premise leads toward the conclusion that defining word meaning can only be achieved by describing the type of situation in which words are used. From this point of view, we would not need to take issue with the Integrationists' claim that context develops as the communication process itself develops, which makes each context (and each process) unique, but which conversely does not "prevent specific features of the situation from remaining constant throughout" (Harris: 1996: 163). 
The uniqueness of the situation (along with its specific features) is also what Radical Contextualists consider sufficient as far as the interpretation of a 'sign' is concerned. Since words are only associated with situations of use, and thus only contribute a "semantic potential" in a communicative exchange, they have to draw their everchanging meanings from somewhere. Accordingly, very much in the spirit of Wittgenstein, the theoretical position of Radical Contextualism is made up of the following ingredients: i) the role of 'similarity' between 'source' and 'target' situations (historical contexts and re-emerging, re-evaluated circumstances); ii) the context-dependence of similarity relations; and iii) the rejection of abstract meanings or 'types' in favour of particular uses (of words).

Let us develop these points in a little more detail. For the first point, I take an example from Recanati (2004: 148). A learner of a predicate, let us say P, observes an application of $\mathrm{P}$ in a particular situation $\mathrm{S}$. In a new situation, $\mathrm{S}$, the learner might conclude that $\mathrm{P}$ only applies if $\mathrm{S}^{\prime}$ is sufficiently similar to $\mathrm{S}$. It is equally possible however that the similarity between $S$ and $S^{\prime}$ as it appears to the learner does not render the use of $\mathrm{P}$ in $\mathrm{S}^{\prime}$ appropriate for the community at large who might therefore reject or correct the learner's usage. In this situation the learner's use of $\mathrm{P}$ will therefore be subject to adjustment. The process could go on indefinitely (following our earlier point that word senses are susceptible to variation, pretty much indefinitely) and thus at some point towards the end of a learning phase a learner might draw the conclusion that a semantic potential of $\mathrm{P}$ is a "collection of legitimate situations of applications" (Recanati 2004: 148) where some level of similarity exists with respect to the conditions of applications of $\mathrm{P}$ (not fixed meanings) between the 'source' situations ( $\mathrm{S}, \mathrm{S}$ ') and a given 'target' situation (let us say $\mathrm{S}$ ', or S', ').

On the second point above, the dimensions of application between the source and target situations continue to be in flux and are underdetermined because the dimensions can continue to vary depending on the situations participants find themselves in. As for the third point, the theory of Meaning Eliminativism, as a radical view within Contextualism (Recanati 2004: 146-151; Hintzman 1986), would insist on disregarding any alleged input from the 'linguistic meaning' of the expression type entirely and would favour an account where communication rests on computing a contextual sense of an expression arrived at purely through its use on a particular occasion on the basis of possible contextual senses the expression had in previous situations. On this view, words are not associated with conventional, linguistic meaning as abstract entities; words are associated with particular contextually determined applications (Douglas 1986, 1988; Recanati 2000, 2004).

Perhaps for Integrationists this position still doesn't go far enough: Radical Contextualists stop short of the integrationist position of 'radical indeterminacy': "[1] anguage is radically indeterminate, as regards both what is meant and what is said" (Love 1990: 105). Furthermore, the Radical Contextualist frameworks still arguably represent inconsistencies as far as the distinction between narrow and wide context is concerned. Harris (1996: 162) acknowledges Firth's (1957) distinction between immediate context and 'a contextualisation of that context' (which Firth calls "sociological linguistics") as an attempt to rescue the 'context of situation' in language theory. Harris however has issue with where one type of context begins and 
the other ends. Many Contextualist theories have since offered a number of possibilities as to how our conscious and unconscious levels of processing rely on various types of contextual information to explain processing mechanisms and reliance on wider context in communicative processes (cf. for example Recanati $2007 \mathrm{~b}$ on primary and secondary pragmatic processes). All this still probably places them in the camp of what the Integrationists would refer to as "weak segregationism", the view that "the relevant communicational unit is not the sign as defined by the linguistic code, but, in practice, the sign-in-its-context" (Harris 1996: 147). Nevertheless, it seems to me that much progress has been made on the side of contemporary philosophy of language in considering and adjusting to the position that a theory of language use cannot be divorced from a theory of communication.

\subsection{The contestable nature of language in practice: the impact of language use on social consciousness}

In this section we return to our protest theme and the data analysis. Many defence campaigns and organisations (amongst them NETPOL - the Network which monitors public order, protest and community policing that is excessive, discriminatory or threatens civil rights), Haldane Society of Socialist Lawyers, Defend the Right to Protest Campaign, many MPs including Caroline Lucas (Green Party) and a considerable number of MPs now occupying positions in the Labour Shadow Cabinet, including its leader and the Shadow Chancellor) contributed towards, and were largely successful in, contesting the widely accepted narrative of this period of student protest. This is evident on two accounts: the acquittal of the majority of protesters, and the relative acceptance of an alternative narrative by the mainstream media. The eventual success of this counter-narrative was also consequent upon an exposure of emerging evidence presented in court hearings and the exposition of inaccuracies and untruths reported in the media. The extracts in previous sections are a testimony to the persistent narrative of violence according to which aggressive actions were exhibited solely on the side of the protesters, thus any retaliation from the police was described as 'defence' and 'protection' as mechanisms in preventing harm and injury to themselves. Readdressing the balance of that narrative required commitment and strength on the part of many militant activists. It should additionally be noted that tireless and persistent work of defence campaigns was the key precursor in raising awareness of these injustices amongst Members of Parliament and legal firms as the vehicle through which the alternative narrative of the events could penetrate through the mainstream media and consequently force the Government to reconsider its own narrative. We see here a multi-layered set of actions that illustrate differences, shifts and processes of flux in language-use in the continuous battle to re-evaluate contexts and reframe the meanings of the terms that for a long time masked the conflict and inhibited the re-development and re-thematisation of meanings antagonistic to the Government.

During the period of the Coalition Government (2010-2015), the heavy police presence, use of a 'kettling' (containment) technique and other forms of targeted violence against protesters became a common sight at demonstrations. The frequent use of kettling requires officers to surround demonstrators in a confined space 
allowing only small numbers out after a lengthy delay. During the student protests in question, kettled demonstrators were held for hours at a time without food, water, or provision of basic sanitary needs. The ambiguous description and similarity in definition of the three most serious charges under the Public Order Act 1986, Riot, Violent Disorder and Affray, which carry a maximum sentence of 10, 5 and 3 years respectively, has meant that each charge could be appropriate in some most unlikely of events, even applying, for example, to a bystander on a protest. Demonstrators faced charges of Violent Disorder for throwing placard sticks in and around the crowd (defined as 'missiles' both in the prosecution evidence and the media narratives), and for being within crowds from which placard sticks and empty water bottles were thrown.

Persistent public exposure of police tactics and behaviour contributed to bringing back the necessary diversity of language use where containment of the dominant narratives by the minority was proving challenging. The social conflicts, not just through demonstrations but now also through language-use, created conditions in which it was possible to contest and refine those received meanings (e.g. the miners' strike at Orgreave, the Hillsborough tragedy, 'Black Lives Matter' campaigns in the UK and the United States). Thus, Voloshinov's methodology of studying discursively expressed social conflict enables us to notice shifts in language use as indicators of change in human consciousness, and so social change.

Changes in language used also reflected and contributed to the emergent bravery of some family members of arrested protestors whose confidence to speak to the media grew with time. By going to the newspapers they contributed to the re-evaluation of previously unchallengeable episodes of police conduct (the extract from a parent's testimony appeared in the BBC's and Channel 4's reporting of the student's acquittal). In the extract below we also see examples of the vocabulary associated with violence and criminalisation but this time from a different perspective: importantly, the evidence presented in court hearings contributed to reshaping the previously deeply-rooted narrative. Below we see that the acts of "criminalisation" and "victimisation" are attributed to the police and the Crown Prosecution Service (CPS). Here, the protesters are described as "peaceful" and "kettled" (a technique condemned in the reconstruction of the narrative associated with the 2010 events and exemplified elsewhere in the paper); "police tactics" are described as "violent" instead. We further see this growing confidence in the counter-narrative in the way in which a pursuit of "justice" is repeated a number of times in the extract, involving an "ordeal" and a "fight" to "clear" students" names. Arguably, this extract is an excellent example of how the language used 'meets' changes in social consciousness taking place through real life struggles.

The struggle for justice for my son has finally begun. Today a jury has delivered a unanimous verdict acquitting [him] of violent disorder....

[Two students] had to wait more than two years and go through the ordeal of three trials to clear their names. Meanwhile the trial has taken a heavy toll on both [of their] families... 
The trial has also exposed the same pattern of criminalisation and victimisation by the police and CPS, which we also saw played out in the cases of the Hillsborough tragedy and the miners' strike at Orgreave.

[My son] suffered a baton blow to the head... which required life-saving brain surgery. While the police have so far escaped any form of accountability for their actions, [he] was charged with violent disorder and has had to fight to clear his name before finally beginning the road to justice.

Of the 15 protesters who pleaded not guilty to charges of violent disorder relating to the 9 December 2010 demonstration, so far 14 have been found not guilty. In a time of unprecedented cuts to public funding, it is atrocious that the police and the CPS have wasted resources in the pursuit of criminalising protesters.

The trial has allowed us to scrutinise what happened on the day of the protest. The peaceful and kettled protesters were charged at with horses and subjected to indiscriminate baton use. When [my son's barrister] challenged... a senior officer in charge of the ground operation on the day, on whether their batons had been used as a last resort, his reply was that the use of a machine gun against protesters would have been the last resort. It transpired that police also considered the use of rubber bullets against the student protesters.

The treatment of [my son] and other student protesters stands in stark contrast to the failure to hold any officers to account for violent police tactics or injuries sustained by protesters. In the wake of this verdict we are reminded that we must fight together to defend our right to protest and for justice for all victims of police violence.

The struggle for justice for my son has finally begun. The whole family has been through two years of total agony. We have been silenced on what happened to our son. We can now move on to the really important thing, which is to get justice... ${ }^{9}$

The following extract, which comes from a defendant's partner, illustrates the psychological effect of state oppression. It further helps us grasp what Voloshinov called 'the contestable nature of language', helping us understand the dynamics of this contest (Collins 1996). Thus, anything that is significant to the life of a social group is subject to their evaluation, from the point of view of their own social position.

Corresponding to the Radical Contextualist position exemplified in previous paragraphs, Voloshinov's framework too emphases the evaluative nature of utterances and the importance of changing evaluations which are contextually determined. There are at least two evident juxtapositions in the 'testimony' below: one between an individual and the state, and another between "the mental" and "the social". With regards to the former, "the protester' is now described as an "isolated individual",

$98^{\text {th }}$ March 2013: http://www.defendtherighttoprotest.org 
"named", "stripped of any context". This is in stark contrast with the state, "anonymous", yet "with multiple faces", in the form of the police, the guards and the prosecutors, all seeking to "penalise" the individual. The theme of "punishment" runs throughout the extract. The state oppression is further exposed in the latter juxtaposition where we see the exposition of the "profound structural wrongs" (the wrongs of the state and the social structures of course), which, from the social position of the said family member must not be dissociated from the "injury, stress and mental illness" for which the state is "directly" responsible, not just for the individual in question but "the broader social whole". The theme of criminality also runs through the text, as has been the case with examples so far, but here it is used to contest the so far unchallenged Government and media narratives. Thus, here we see explicit reference to the police officer who hit the protester over the head with his truncheon and caused life-threating head injury; the exposure of the senior police officers' false testimony, and their discussion of a possibility of using machine guns on protesters.

Any supposed polarisation between 'the mental' and 'the social' is torn apart in situations where political activity puts you in direct confrontation with the state.

When the state's actions are directly responsible for injury, stress and mental illness, it is imperative that we do not dissociate one from the other. We cannot continue to blame individuals for profound structural wrongs.

The individual is only a symptom of the broader social whole. For decades now, (anti-)psychiatrists, activists and political thinkers have said that mental health cannot be dissociated from the pathologies of the culture in which individuals are deemed to be unwell.

I want to talk about the personal impact of a serious, prolonged encounter with the criminal justice system, and the collective impact this continues to have on friends and family. Above all, I want to stress that the way in which the state uses time as a method of punishing, even before it seeks to actually penalise you...

This stretching out of time is a central feature of what punishment is, from the slowness of bringing someone to trial, to the trial process itself, to prison, the purest manifestation of time used as a weapon, against the very nature of what it means to be human.

The implications for mental health, with the anonymous, seemingly indifferent state with its multiple faces - the police, the prosecutors, the guards - against isolated individuals, named, stripped of any context, are extreme: and it is always the most vulnerable who end up in the worst places, with around 70 per cent of prisoners suffering from two or more mental health disorders.

In December 2010, my partner... was nearly killed by the police when an officer at an anti-tuition fees demo hit him over the head with a truncheon. 
After recovering from the brain surgery that saved his life, he was charged with a serious public order offence. This was despite, or indeed, because of the fact that there was video footage of (and documentation relating to) the attack on him.

Police bloggers nevertheless continued to spread disinformation that [he] had been hurt by another protester, repeatedly claiming that he had been hit by a concrete block. The frustration and anger about not being able to speak out about the truth of the situation online only made the situation more upsetting....

.... We were all suffering. Seeing the state up close, seeing senior police officers lie and discuss how they would have turned machine guns on protesters, how they had called for rubber bullets, how the students had 'asked for it' - was extremely distressing...

When jury members cried at the footage of protesters being smashed with shields, hit with batons, charged with horses and crushed on Westminster Bridge we cried too, even though we had seen all the footage many times before...

\section{Shine A Light, 28 April 2014}

In the wake of student trials, increasing questioning of police conduct and the emergence of alternative narratives contesting the Government's misrepresentation of facts, the media reporting moved to some extent from a discourse in which all protest inevitably leads to violence and criminality, to a relatively neutral reporting of the outcomes of the trials. That reporting included a range of testimonies and experiences of those close to the protesters (as above), as well as elements of interviews conducted with the protesters themselves so that their voices could finally be heard. Simon Israel, Channel 4's Senior Home Affairs Correspondent at the time, was one of the few recognised figures in the media who took an interest in the cases in question. During one of the trials his report for Channel 4 exposed unacceptable police tactics, but stopped short of demanding any form of accountability from the police and the Government. His report on the acquittals of two protesters includes some recognition of the evidence of police aggression as witnessed in court through CCTV footage:

...He [the protester] said he witnessed police attack and had seen other demonstrators being hit and crushed in one corner of Parliament Square.

The jury were told the police used aggressive tactics to herd protestors into an area where there was no way out in a policy described as kettling.

Footage caught [him] with his hand on a railing which was being forced against a police line. [He] explained his aim was to defend other people and he had no intention of hurting or injuring any police officer and in doing was clubbed over the head with a police baton. 
He said; "one police officer was waving his baton above his head, I turned my back, then felt a huge blow."

The student required emergency brain surgery. An Independent Police Complaints Commission inquiry was put on hold until the trial process was over. It said tonight it was meeting with [the] lawyers about reopening the inquiry.

Channel 4, 8 March 2013.

Lastly, I return to the case of a student protester touched upon in section 2.1. The protester was charged with Violent Disorder on false testimony according to which the police officer involved in the incident had been dragged off his horse and beaten. The jury returned a unanimous acquittal verdict and dismissed the testimonies of nine police officers. We saw earlier that the narrative based on such false testimony had flooded mainstream media and even found its place in the Prime Minister's statement (later withdrawn) calling for the "full force of the law" against those who "assault" police and cause damage to property. This particular case additionally exposed the tactic of collusion between police officers as evidenced from other cases of prosecution and civil suits arising from the 2010 demonstrations ${ }^{10}$. The campaigners in this case called for a public enquiry into the violent police tactics including the use of horse charges, baton strikes and containment of protesters.

In their apology to the student, the Metropolitan Police wrote:

$I^{11}$ write with regard to the incident that occurred on 9 December 2010 during the course of major public disorder at a student protest. During the course of the protest, and following an incident when a police officer fell off his horse, you were struck with police batons, handcuffed and arrested for assault on police. You were subsequently charged with violent disorder and stood trial on two occasions and eventually acquitted.

The purpose of this letter is to apologise on behalf of the Metropolitan Police Service for the distress and upset that you suffered as a result of your arrest.

...On this occasion, and on the facts as known, it would appear that the level of service has fallen below the requisite standard and you should not have been arrested.

I would therefore like to express my regret for the distress and injury that you suffered as a result of this failing. ${ }^{12}$

\footnotetext{
10 Footnotes 5, 6 and 7 give relevant information.

11 The letter was signed by Jill Horsfall, Chief Inspector, Directorate of Professional Standards.

12 Since the trial was concluded in 2015 , the letter has been publicly available, with permission of the student protester involved: http://www.defendtherighttoprotest.org/mets-apology-to-christopher-andandrew-hilliard-calls-for-a-public-inquiry-into-policing-of-student-protests/
} 
The political significance of the letter cannot be underestimated. Its emergence is a direct consequence of painstaking campaigning to contest and re-evaluate dominant discourses perpetuated in the media. The types of narratives that prevailed for a long time were a direct consequence of the power and domination of the Government at pains to emphasise the violent, aggressive behaviour of the protesters, which in turn justified a disproportionate use of force by the police that in many cases resulted in serious injury to protesters as well as danger to life. Crucial to the protesters' victory was the concerted deployment of language as a social power in relation to two aspects of the conflict: a) the specificities of the context in which the incident took place and the evidence available in court to show police collusion; and b) the assiduous work of campaigners and activists in helping to redefine received meanings around why the demonstrations occurred in the first place. We see here that meanings produced earlier around assault and violence in a new situation generate quite different, new, meanings. These negate the Government's case and open up opportunities for new discourses where the conduct and role of the police can be questioned from a position of strength; such alternative narratives then continue to influence changes in the dynamics of power relations between protestors, police, government and media which ultimately help to create the possibility for the subsequent acquittal.

I hope that the reader is able to see the value of examining this episode of student protest by applying some elements of Voloshinov's framework. The material drawn on here has enabled us to study the dynamics of a contest between competing political narratives on the role of the police in society.

\subsection{Relevance of Voloshinov to contemporary debates in philosophy of language}

Attempts by several Radical Contextualists and integrationists to challenge some aspects of the longstanding Gricean position on utterance meaning in context (and its consequences for the theory of mind) should in my view be acknowledged as a positive step toward greater integration between theories of language and theories of communication in general. This paper has attempted to offer a contribution to this debate through the analysis of a particular case study which allows us to introduce the position on word meaning outlined by Voloshinov. The case study of narrative and counternarrative around the 2010 student protests demonstrates a dynamic sociopolitically driven process of (re)evaluation of language use in particular situations. On that basis, I have argued that the indefinitely changing character of word meanings can only be accounted for by describing the type of situation in question. One of the consequences of this approach is that discourse (in the sense of concrete utterances in context) 'absorbs' relevant aspects of its context of use, thereby 'fusing' with its context and generating new contextual senses which can, in turn, following Voloshinov (1986: 83-106), be re-deployed, re-contextualised and re-evaluated (positively or negatively) in ensuing social encounters. Accordingly, from the position of contemporary philosophy of language, this approach would entail a complete elimination of the distinction between de Saussure's 'langue' and 'parole', and so an abandonment of 'types' in favour of particular uses. 
Arguably, this is a good starting point to begin to incorporate into contemporary debates Voloshinov's critique of approaches which see language as a stable system of "normatively identical forms", and which are only useful perhaps for instructional purposes, thus removed from the inherently social context of language use. Voloshinov adds that this kind of abstraction is "not adequate to the concrete reality of language" (1986: 94). To show further the importance Voloshinov attributes to the language of 'real life', it is worth quoting him in full (1986: 95):

Any utterance, no matter how weighty and complete in and of itself, is only a moment in the continuous process of verbal communication. But that continuous verbal communication is, in turn, itself only a moment in the continuous, all inclusive, generative process of a given social collective.

Voloshinov recognises the complexities in explaining the connection between interactions via utterances on the one hand and that of the "extraverbal" situation (both the immediate situation and the broader situation) on the other. These connections are unstable and diverse because different factors are at play or in focus in different situations with consequences for how concrete meanings will be formed and altered in such situations: He continues (1986: 95):

Verbal communication can never be understood and explained outside of this connection with a concrete situation. Verbal intercourse is inextricably interwoven with communication of other types, all stemming from the common ground of production of communication... Language acquires life and historically evolves precisely here, in concrete verbal communication, and not in the abstract linguistic system of language forms, nor in the individual psyche of speakers.

Previous sections have attempted to provide an illustration of the application of such a position: different textual extracts have indicated an evolving and ever-changing use of language, largely stemming from a "production of communication" (Voloshinov 1986: 95) in fluctuating political contexts.

This particular area of enquiry (i.e. the role of ideology and social consciousness in examining fluxes in language use) has not made itself felt in any contemporary philosophical framework', whether on the Contextualist or Integrationist side discussed in this paper or in approaches more akin to Ideal Language Philosophy (e.g. Minimalism, namely advocated by Bach (cf. 1999, 2004) and Borg (cf. 2007)). This element is a powerful component of Voloshinov's work, however, and it is distinctly historical materialist in nature. If we accept his position that human consciousness does not exist without socially organised individuals who communicate through the use of signs, then perhaps it is relatively straightforward to see how both ideology and 
human consciousness, as inherently social phenomena, are interconnected with the ways in which we use those signs and consequently language itself (Collins 2000). ${ }^{13}$

Nevertheless, there are clear points of possible compatibility and convergence between Voloshinov's position and the Radical Contextualist and Integrationist positions. If from Radical Contextualism we take away the central message that context of use must take primacy in any theory of language, then we are in a stronger position to argue for the socio-political significance of language and critically examine how forms of speaking alter within and between social groups in a changing and developing world. Similarly, the 'radical indeterminacy' principle of Integrationism highlights the fact that the forms and meanings of utterances are always contested, always 'up for grabs' in the concrete context of language use. Both such approaches would lend themselves to the critical exposure of the ways in which the language of powerful minorities is intended to marginalise subordinate communicative forms and meanings and to impose those minority forms in the management of society. Since language use holds such strong power in terms of the impact on social change, it is the duty of critical language researchers to place social and historical contexts of verbal interaction at the centre of their study.

\subsection{Conclusion}

In closing, this paper has sought to engage the reader in key aspects of Voloshinov's philosophy of language by illustrating its relevance for examples that the reader might still consider current. Consequently the reader can detect the importance and value in rescuing the 'social' in language theories, for two reasons: firstly, to contribute to linguistic and pragmatic studies of language and, secondly, to alert the reader to the relevance for contemporary debates in the philosophy of language of the Marxist conception of language which challenges us to engage with and contest the injustices so prevalent in the world yet so skilfully masked by the dominant narratives around us. We hope to have illustrated therefore the use-value of language and the significance of engaging with the language of 'actual life'.

In terms of current debates, we have highlighted the issues at stake over meaning and context between Radical Contextualism and Integrationism. Radical Contextualism has, it seems, come close to the Integrationist approaches which have met such resistance in academic circles for the significant challenges they pose not only to contemporary philosophies of language but also to those scholars who have broadly adopted a 'segregational' (decontextualized) view of linguistic systems underlying linguistic behaviour. Whether words have a communicational value which is unique to particular interactional contexts (Integrationism) or whether they contribute something that might be called a pre-existing 'semantic potential' to an ongoing communicative act (Radical Contextualism) appears to be a line that demarcates the two positions. Nonetheless, we hope to have shown that there are sufficient parallels between the two approaches to afford opportunities for productive dialogue. More

13 We note however that the whole field of Critical Discourse Analysis (CDA) (e.g. Fairclough 1992; Wodak and Meyer 2001) and the work of Jones and Collins (e.g. 2010) deal with this area of enquiry; Jones (e.g. 2011) specifically taking up the Integrationist position. 
particularly, we hope to have re-vitalized this debate by giving Voloshinov's pioneering 'Marxist philosophy of language' the central place it deserves within the study of language in context. The significance of Voloshinov's contribution to contemporary debates is that it directs us towards political struggle and social conflict as the most important dimension and driving force in the linguistic 'construction of context' at specific conjunctures, a dimension which Radical Contextualism and Integrationism have tended to ignore. A 'confrontation' between Voloshinov's 'Marxist philosophy of language', Radical Contextualism and Integrationism may therefore help to expose and illuminate the theoretical limitations of the latter while at the same time amplifying, concretising and, possibly, correcting the former through a grounding in more general communicational principle.

\section{Bibliography}

Bach, K. 1999. The Semantics-Pragmatics Distinction: What It Is and Why It Matters. In Turner, K. (ed.) The Semantics-Pragmatics Interface from Different Points of View. Oxford: Elsevier.

Bach, K. 2004. Minding the Gap. In Bianchi, C. (ed.) The Semantics/Pragmatics Distinction. Stanford: CSLI.

Barker, C. 2010. Ideology, Discourse and Moral Economy: Consulting the People of North Manchester. In Huspek, M. (ed.) Oppositional Discourses and Democracies. London: Routledge.

Borg, E. 2007. Minimalism versus Contextualism in Semantics. In Preyer, G. and Peter, G. (eds.) Context-Sensitivity and Semantic Minimalism. New Essays on Semantics and Pragmatics. Oxford: Oxford University Press.

Carston, R. 2007. How Many Pragmatic Systems are There? In Frápolli, M. J. (ed.) Saying, Meaning and Referring. Essays on François Recanati's Philosophy of Language. Basingstoke: Palgrave Macmillan.

Collins, C. 1996. To concede or to contest? Language and class struggle. In Barker C. and Kennedy, P. (eds.) To Make Another World. Studies in Protest and Collective Action. Aldershot: Avebury.

Collins, C. 1999. Language, Ideology and Social Consciousness: Developing a Sociohistorical Approach. London: Routledge.

Collins, C. 2000. Vygotsky on Language and Social Consciousness: Underpinning the Use of Voloshinov in the Study of Popular Protest. Historical Materialism 7(1), 41-69.

Collins, C. 2013. Language, Marxism and the Grasping of Policy Agendas: Neoliberalism and Political Voice in Scotland's Poorest Communities. In Barker, C. Cox, L, Krinsky, J and A. G. Nilsen (eds.) Marxism and Social Movements. Chicago, IL: Haymarket Books. 
Douglas, H. 1986. 'Schema Abstraction' in a Multiple-Trace Memory Model. Psychological Review 93, 411-428.

Douglas, H. 1988. Judgements of Frequency and Recognition Memory in a MultipleTrace Memory Model. Psychological Review 95, 528-551.

Fairclough, N. 1992. Discourse and Social Change. Cambridge: Polity Press.

Firth, J. R. 1957. Papers in Linguistics 1934-1951. Oxford: Oxford University Press.

Goodwin, C. 2013. The co-operative, transformative organisation of human action and knowledge. Journal of Pragmatics 46, 8-23.

Harris, R. 1981. The Language Myth. London: Duckworth.

Harris, R. 1996. Signs, Language and Communication. London: Routledge.

Harris, R., 1998. Making sense of communicative competence. In Harris, W. (ed.), Integrational Linguistics: a First Reader. Oxford: Pergamon.

Hintzman, D. 1986. Schema Abstraction in a Multiple-Trace Memory Model. Psychological Review 93, 411-428.

Hutton, C. and Bade, D. 2011. Roy Harris and Integrational Linguistics. Language Sciences 33, 475-479.

Jones, P. E. 2004. Discourse and the Materialist Conception of History: Critical Comments on Critical Discourse Analysis. Historical Materialism 12:1, 97125.

Jones, P. E. 2011. Signs of activity: integrating language and practical action. Language Sciences 33, 11-19.

Jones, P. E. 2016. 'Coordination (Herbert H Clark), ‘integration' (Roy Harris) and the foundations of communication theory: common ground or competing visions? Language Sciences 53, 31-43.

Jones, P. E. and Collins, C. 2010. State Ideology and Oppositional Discourses: Conceptual and Methodological Issues. In Huspek, M. (ed.) Oppositional Discourses and Democracies. London: Routledge.

Lecercle, J-J. 2006. A Marxist Philosophy of Language. Chicago, IL: Haymarket Books.

Love, N. 1990. The locus of languages in a redefined linguistics. In Davis, H.G. and Taylor, T.J. (eds.) Redefining Linguistics. London: Routledge.

Marx, K. and Engels, F. 1845/1974. The German Ideology. In Arthur, C. J. (ed.). New York: New York International Publishers. 
Medina, J. 2005. Language. Key Concepts in Philosophy. London: Continuum.

Morris, P. (ed.) 2003. The Bakhtin Reader: Selected Writings of Bakhtin, Medvedev, Voloshinov. London: Arnold.

Predelli, S. 2005. Contexts: Meaning, Truth, and the Use of Language. Oxford: Clarendon Press.

Recanati, F. 1997. The Dynamics of Situations. European Review of Philosophy 2, 41-75.

Recanati, F. 1999. Situations and the Structure of Content. In Murasugi, K. and R. Stainton (eds.), Philosophy and Linguistics. Colorado: Westview Press.

Recanati, F. 2000. Oratio Obliqua, Oratio Recta. An Essay on Metarepresentation. Massachusetts: MIT Press.

Recanati, F. 2002a. What is Said and the Semantics/Pragmatics Distinction. In Bianchi, C. (ed.) The Semantics/Pragmatics Distinction. Stanford: CSLI.

Recanati, F. 2002b. Pragmatics and Semantics. In Horn, L. and Ward, G. (eds.) Handbook of Pragmatics. London: Blackwell.

Recanati, F. 2004. Literal Meaning. Cambridge: Cambridge University Press.

Recanati, F. 2007a. Perspectival Thought. A Plea for (Moderate) Relativism. Oxford: Oxford University Press.

Recanati, F. 2007b. How Many Pragmatic Systems Are There? Reply to Carston. In Frápolli, M. J. (ed.) Saying, Meaning and Referring. Essays on François Recanati's Philosophy of Language. Basingstoke: Palgrave Macmillan.

Stainton, R.J. 2010. Philosophy of Language. Introduction: preliminaries and game plan. In Cummings, L. (ed.) The Routledge Pragmatics Encyclopedia. Abingdon: Routledge.

Travis, C. 1997. Pragmatics. In Hale, B. and Wright, C. (eds.) A Companion to the Philosophy of Language. Oxford: Blackwell.

Travis, C. 2008. Introduction to Occasion-Sensitivity: Selected Essays. Oxford: Oxford University Press.

Voloshinov, V. N. 1929/1986. Marxism and the Philosophy of Language. Cambridge, Massachusetts: Harvard University Press.

Wodak, R. and Meyer, M. 2001. Methods of Critical Discourse Analysis. London: Sage. 